\title{
ПОАИТИЧЕСКИЕ КОММУНИКАЦИИ
}

Ауняева М.М.

\section{РОАЬ И ЗНАЧЕНИЕ \\ СРЕАСТВ МАССОВОЙ КОММУНИКАЦИИ В СОВРЕМЕННЫХ ПОАИТИЧЕСКИХ ПРОЦЕССАХ}

\begin{abstract}
Аннотация. Предметом статьи является деятельность средств массовой коммуникации в ходе военных и политических конфликтов, их роль и место в ходе информационного противостояния междугосударствами. Авторомуточняются такие понятия как «медиа», «медиакоммуникация», выделяются особенности, условия и возможности воздействия современных медиа на политические процессы. Авторомизучаются такие понятия как «медиа», «медиакоммуникация», особенности условия ивозможности воздействия современныхмедиана политическиепроцессы современногомира. В работерассмотрены процессы информачионного противостояния, каксоставнаячастьполитического процесса. Теоретическими основами статьивыстиупают труды отечественныхизарубежных ученых - специалистов вобластиконфликтологии, современныхинформачионных иполитических процессов. При решении поставленных задач к использованы как общие, так и частные методы исследования: в первую очередь системный, диалектический, логический, и функциональный методы, методы анализа и синтеза, эмпирические методы, метод прогнозных сиенариев, контент-анализа. Научная новизна исследования заключается в обосновании новых подходов к роли и месту средств массовой коммуникации в ходе военных, государственных и политических конфиктов, уточнении механизмов информационного противостояния в современных условиях, а также в использовании концептуальных наработок при изучении мирового информационного противостояния.
\end{abstract}

Ключевые слова: Коммуникация, политика, медиа, общество, средства массовой информации, информационное противостояние, медиакоммуникация, политические прочессь, политический дискурс, информачионное общество. 
реАства массовой коммуникации (СМК), в качестве среАств повсеАневной практики сбора, обработки и распространения информации, преАназначенной Аля массовых аудиторий ${ }^{1}$, в настоящее время все более приход на смену траАиционным среАствам массовой информации (СМИ). При этом они непосреАственным образом воздействуют как на экономические и социальные, так и на политические процессы, что Аелает их, совершенно особым общественным институтом и опреАеляет научную актуальность их анациза.

Ааже среАства массовой информации, заАолго Ао появления концепций «информационного общества», и, соответственно, Ао его формирования, признавамись весомым политическим актором, рассматрива ись в качестве «четвертой власти» государства. В условиях же, современного перехода к информационному обществу, СМК облаАают существенно большими механизмами возАействия на политические процессы, чем традиционные СМИ, именно в силу новых их качеств - в первую очереАь их «меАийности».

Тот факт, что «траАиционные» СМИ, в настоящее время или «отмирают» или переходят в новое качественное состояние (СМК), используя возможности меАиаком-

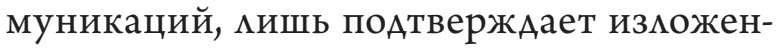
ную нами посылку.

КАючевым понятием, характеризующие современные СМК явмяется термин «меАиа», который вкмючает в себя всю совокупность технологических среАств иприемов, служащих Аля переАачи конкретному потребителюинформационного сообщения

\footnotetext{
1 Новикова А.А. СреАства массовой коммуникации в эпоху глобамизации. - В 3. Т.- М., 2012.- Т. 1.- С. 11.
}

в том или ином виАе, в том числе, в качестве инструмента политического и иАеологического вАияния ${ }^{2}$.

Еще оАно важнейшее понятие - коммуникация, поАкоторой мыбудемпонимать информационное возАействие субъекта коммуникации на объект, преслеАующее цели, заданные субъектом (в Аанном случае имеется в виду социацьная коммуникация, искиючающая её технические аспекты, относящиеся к разряду среАств коммуникации).

Современная теория коммуника ции, в связи с ростом значения меАиа, а также появлением новых видов коммуникации, также стала нужАаться в термине, позвоцяющем синтезиро вать массовую коммуникацию и межличностную коммуникацию, более того - в выдемении особого типа коммуникации, который Ааст возможность гово рить о коммуникации внутри меАиаполя. Таким термином и стала меАиакоммуникация, которое, как несложно преАположить, образовано путем соеАинения понятий «меАиа» и «коммуникации».

Под меАиакоммуникацией, в современной науке понимается распространение (с помощью технических среАств) межАу разАичными группами и инАивиАУумами специально поАготовленных сообщений,

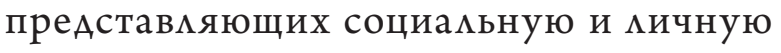
значимость ${ }^{3}$.

Нами, меАиакоммуникация опредемяется как процесс созАания, трансляции, обмена информацией меАиа в индивидуацьном, групповом, массовом формате по размичным каналам при помощи разАичных

\footnotetext{
2 См. напр.: Почепцов Г. Г. Теория коммуникации. - M., 2008. - C. 48-19.

3 Киричёк П.Н. МеАиакоммуникация и массовое сознания. - М., 2009. - С. 17-18.
} 
коммуникативных срелств (вербальных, невербальных, аудиамьных, визуальных, проч.).

Характерные черты современной меАиакоммуникации, связаны с ее сетевым характером и выражаются в ${ }^{1}$ :

- интегративности - вкмючение свойств меАиа-преАшественников (периодическая печать, ТВ и т.А.);

- интерактивности - порожАение специфических форм социамьных сетей и социальной интеграции.

Характерными особенностями меАиакоммуникации явмяются:

- потенциальная возможность осуществления коммуникации кажАым без ограничения во времени и пространстве (anyone/anytime/anywhere);

- отсутствие централизованного управмения;

- самостоятельность;

- паутинный, нелинейный характер взаимодействия

«Новые» меАиа (СМК) преАставмяют собой традиционные меАиа (СМИ), преобразованные в цифровой формат и имеющие возможность быть преАставленными в сети интернет, отличающиеся такими новыми характеристиками, такими как мумьтимеАийность, интерактивность, многоканамьность. Новые форматы медиа, способны непрерывно обновмять информацию ипреАоставцять ее в режиме реацьного времени.

Как слеАствие - в сети стал формироваться меАийный сектор со своими производитемями и целевыми ауАиториями, которые обращаются за помитическими новостями в интернет, гАе обновмение информации происходит в режиме реаць-

\footnotetext{
1 Киричёк П.Н. Медиакоммуникация и массовое созна-
} ния. - М., 2009. - С. 54-56. ного времени. Следует отметить, что это относится не только к сайтам, но и блогам и социальным сетям, несмотря на то, что социальные сети, строго говоря, среАствами массовой информации в траАиционном понимании не явмяются.

Информатизация общества способствовала росту роли информации, специфике ее подачи, созАанию мультимеАийного, специализированного контента Аля пользовате-

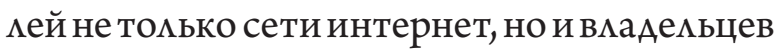
смартфонов, планшетов и Аругих эмектронных устройств небольшого формата слоступом к интернету ${ }^{2}$.

Как следствие - новые информационные технологии стремительно меняют порядок жизни общества, воздействуя тем самым на все его «поля» (пользуясь терминологией П. БурАьё $\left.{ }^{3}\right)$ - экономическое, культурное, социальное и политическое.

Таким образом, в современную эпоху массовой культуры и массовых коммуникаций существенно усимивается власть СМК в информационно-символическом поле по$\Lambda$ итики, что проявцяется в формировании и интенсивном развитии коммуникативной среАы под названием «политическая меАиареальность ${ }^{4}$.

ПоА политической меАиа-реальностью в науке, понимается виртуацьная политическая реальность, сформированная вслеАствие медиатизации политики ${ }^{5}$. В свою очереАь, меАиатизация политики преАставляет собой АиффУзию политического и меАийно-

\footnotetext{
2 Виннер М. Социальные сети.- М., 2011.- С. 21.

3 См. подр.: БурАьё П. Социология политики / Пер. с фр. Н.А. Шматко. - М., 1993.

4 Ауман Никлас. Реальность массмедиа.- М., 2005.— С. 32.

5 Ноэмь-Нойман Э. Общественное мнение. Открытие спирали молчания.- М., 1996.- С.19.
} 
го пространств, в результате чего происхоАит перетекание политических символов и смыслов из области объективных политических практик в область виртуацьномеАийную.

Ужев современных условиях, Аля подавмяющего большинства гражАан основным источником получения информации о помитической реацьности выступают масс-меАиа. Масс-медиа формируют преАставления о событийной структуре политической реацьности, ранжируют явления политической жизни по определенным шкалам их социа ьной значимости, выступают интерпретаторами и смыслооформителями фактов политики.

Медиа выступают, таким образом, с оАной стороны, фильтрами, отбирающими Аля массовой аудитории группы и направмения актуамьных политических проблем, а, с Аругой стороны,- «Аизайнерами» виртуальной политической реальности, на основании которой гражАане выносят свои сужАения о политике.

Более того, именно СМК обладают сеГоАня наибольшими техническими и идеологическими возможностями по формированию векторов общественного мнения и Аоминант политических преАпочтений публики. Все эти возможности могут использоваться и уже активно используются в качестве инструмента медиакоммуникаций в процессе развития Аиалога межАу обществом и госуаарством. Косвенным поАтвержАением этого процесса, на наш взгляА, явАяется тот факт, что основные общественно-политические силы все больше внимания уделяют этой новой информационно-коммуникативной среАе.

Быстрый рост роли информации в жизни общества, продолжается и по сей день. Это обусловлено бурным развитием высо- кихтехнологий, всех отраслей производства и накопиения опыта рыночных отношений. Владение информацией стало опредемяющей преАпосылкой успеха в условиях жесткой рыночной конкуренции; технологические усовершенствования, изобретения, ноу-хау превратикись в ценный товар ${ }^{1}$.

ОАнако рост веса информационного фактора в политической сфере обусловлен не только влиянием сферы технологической ими экономической. Разработка эффективной Аолгосрочной стратегии, аАекватное реагирование на события и изменения в поАитической среАе невозможны без полной и Аостоверной информации о состоянии политической среАы, Аействия и намерения Аругих политических игроков. Особое значение информационный фактор приобрел еще в середине в XX в. в связи с развитием и распространением демократии как формы правления, при которой источником власти явцяется не оАно Аицо или группа Аиц, а весь народ ${ }^{2}$.

Такое превращение народа в субъект политики требует максимально полного и объективного информирования всех граЖАан о политической Жизни (что в сереАине ХХ века, осуществлямось через СМИ)

В современном же информационнокоммуникативном пространстве, потребность объективного информирования о помитической жизни, проявцяется на новом уровне в новых формах информационнокоммуникативных взаимодействий, основным институтом которых, явцяется СМК.

\footnotetext{
1 ТютюнАжи И.М. Интернет коммуникации общества и вмасти в России и США в XXI веке: сравнительный социологический анализ: автореф. Аисс. к-та соц. наук.- М., 2012.- C. 21.

2 Кравцов В.В. Инновационная политика и власть в современном меАийном пространстве: Автореф. Аисс. А-ра филос. наук. - M., 2012.- С. 24.
} 
ОАнако, в рамках современных демократических преАставмений о взаимоотношениях государства и общества, более корректно и целесообразно говорить не столько об управлении, сколько о взаимодействии общества и госуАарственной вмасти, эффективность которого во многом становится залогом стабицьного и успешного развития веАущих мировых Аержав. При этом сегоАня на первый план выходит взаимодействие в первую очереАь именно информационное, как одно из наиболее перспективных направлений Аахьнейшего развития современных Аемократий. В этихусловиях, меАиа выполняют и еще оАну функцию — в качестве связующего звена межАу государством и гражАанским обществом.

В целом, можно утвержАать, что меАиа, в настоящее время, активно взаимодействуют со всеми институциональными системами общества, активно вмияя и на национацьную и мировую политику. СреАи особенностей этого «вАияния», можно отметить следующее:

- во-первых, государство, точнее ее политические институты, постепенно теряют контроль наА содержанием информационных сообщений;

- во-вторых, медиа получают все больше возможностей влиять на общественное мнение, мобимизовать ее, освещая глобамьные конфмикты в тот или иной способ;
- в-третьих, развитие новых коммуникационных технологий и реальные Аиспропорции межАу развитыми и беАным странам относятся к СМИ новые требования, на которые те не всегаа реагируют адекватно. Все упомянутые аспекты явмяются важными ориентирами, какА я политиков, так иАля масс-медиа.

Аанные особенности и тенденции, характерны практически Аля всех современных госуаарств, развивающихся по Аемократическому пути. Не искиючением зАесь явияется и Россия.

ИсхоАя из самой своей сУщности, современные меАиа могут предоставлять общественности информацию, необхоАимую Аля понимания политических процессов; являются среАством вАияния масс на политических ииц, принимающих решения. Иными словами, меАиа можно расценивать как неотъемлемую часть общественно-политического процесса, способствующую участию более широких групп населения, в выработке государственной политики.

Таким образом, современное медийное пространство стало политическим актором и оАновременно иАеа ьной площаАКой Аля формирования политического Аискурса, относительно свободного от контролявласти, ААя комментирования актуа ььной «повестки Аня» и вАияния на нее.

\section{Бибмиография}

1. Бурдьё П. Социология политики / Пер. с фр. Н.А. Шматко.- М., 1993.— 439 с.

2. Виннер М. Социамьные сети.- М., 2011.-312 с.

3. Киричёк П.Н. МеАиакоммуникация и массовое сознание.- М., 2009. - 295 с.

4. Кравцов В.В. Инновационная политика и власть в современном медийном пространстве: автореф. Аисс. А-ра филос. наук.- М., 2012.- 29 с.

5. Ауман Н. Реальность массмедиа.- М., 2005.- 271 с. 
6. Новикова А.А. СреАства массовой коммуникации в эпоху глобализации.-- В 3. Т.М., 2012.- Т. 1.- 430 c.

7. Ноэль-Нойман Э. Общественное мнение. Открытие спирали молчания.—M., 1996.— $389 \mathrm{c}$.

8. Почепцов Г.Г. Теория коммуникации.- М., 2008. - 346 c.

9. ТютюнАжи И.М. Интернет коммуникации общества и власти в России и США в XXI веке: сравнительный социологический анализ: автореф. Аисс. к-та соц. наук.M., 2012.- 31 c.

\section{References (transliterated)}

1. Burd'e P. Sotsiologiya politiki / Per. s fr. N. A. Shmatko. - M., 1993. - 439 s.

2. Vinner M. Sotsial'nye seti.-M., 2011.—312 s.

3. Kirichek P.N. Mediakommunikatsiya i massovoe soznanie.-M., 2009.—295 s.

4. Kravtsov V.V. Innovatsionnaya politika i vlast» $\mathrm{v}$ sovremennom mediinom prostranstve: avtoref. diss. d-ra filos. nauk.—M., 2012.—29 s.

5. Luman N. Real'nost» massmedia.-M., 2005. - $271 \mathrm{~s}$.

6. Novikova A. A. Sredstva massovoi kommunikatsii v epokhu globalizatsii.— V 3. T.- M., 2012.- T. 1.- $430 \mathrm{~s}$.

7. Noel'-Noiman E. Obshchestvennoe mnenie. Otkrytie spirali molchaniya._M., 1996._389s.

8. Pocheptsov G. G. Teoriya kommunikatsii.—M., 2008.—346 s.

9. Tyutyundzhi I.M. Internet kommunikatsii obshchestva i vlasti v Rossii i SShA $v$ KhKhI veke: sravnitel'nyi sotsiologicheskii analiz: avtoref. diss. k-ta sots. nauk.— M., 2012.—31 s. 